\title{
The Quality of Catholic Education of Diocesan Schools in the Province of Antique
}

\author{
Rita O. Banusing ${ }^{1}$ and Joel M. Bual ${ }^{2}$ \\ ${ }^{1}$ St. Vincent's High School of San Remegio, Inc., Antique, Philippines \\ 2Pandan Bay Institute Inc., Pandan, Antique, Philippines
}

\begin{tabular}{l} 
Article history \\
Submitted: 2 July 2020 \\
Revised: 26 October 2020 \\
Accepted: 12 November 2020 \\
\hline Keywords: \\
Education \\
Management \\
Catholic Education \\
Diocesan Catholic Schools \\
Descriptive-Correlational \\
Antique
\end{tabular}

Introduction. The mission of Catholic schools is linked to the evangelizing thrust of the Church in proclaiming Christ to the world to transform society. However, most Catholic institutions nowadays are confronted with issues on the deterioration of values, migration of qualified teachers to public schools, and decline in enrolment, posing threats to the Catholic identity and mission, operational sustainability, and quality of teaching and learning (Bual \& Madrigal, 2018; Madrigal \& Oracion, 2019). To address these problems, the Catholic Educational Association of the Philippines (CEAP) developed the Philippine Catholic Schools Standards (PCSS) to help these schools in the country revisit and re-examine their institutional practices according to the identity and mission of the Catholic Church. Hence, this paper assessed the quality of Catholic education of diocesan schools in the Province of Antique in the light of Catholic identity and mission, leadership and governance, learner development, learning environment, and operational vitality domains of PCSS. Also, it sought to find out whether a significant relationship exists between the age, sex, length of service, and designation of assessors and their quality assessment on Catholic education.

Methods. The descriptive-correlational design was used to assess the quality of Catholic education of diocesan schools in the Province of Antique in the light of the domains of PCSS during the school year 2019-2020. Also, the quality assessment was correlated with the demographics of the assessors. A total of 120 school personnel responded to the study: the whole population of 7 administrators, 18 non-teaching personnel, and 95 basic education teachers determined through stratified random sampling. The data were collected through a standardized PCSS questionnaire and rated as follows: 1- initially meets benchmark, 2 - partially meets benchmark, 3 - fully meets benchmark, and 4 exceeds benchmark. The descriptive and inferential analyses were employed in analyzing the data, particularly the Mean, Standard Deviation, Eta correlation, and Pearson r.

Results. The level of quality education in the diocesan schools in Antique was generally rated as "fully meets benchmark." Interestingly, all domains were also rated "fully meets benchmark." Correspondingly, the full benchmark rating indicates that these diocesan schools fully adhere to the quality standards set by PCSS, as supported by the exceptional documentary evidence. However, continuous improvement is needed since they did not meet the exceeding benchmark. In terms of correlation, the results showed no significant relationship between the quality assessment and the school personnel's age, sex, and length of service. In other words, these demographics do not influence their judgment on the quality assessment of Catholic education. However, in the context of designation, there is little, if any, relationship which manifests that the positions of the personnel in the school slightly affect their rating on the quality assessment.

Conclusion. The diocesan schools achieve the quality of Catholic education when they meet the exceeding benchmarks. Moreover, they can fulfill this when they religiously adhere to the quality standards of the PCSS and the continuous improvement of all aspects of operation relative to the domains. Furthermore, to excellently maintain the Catholic identity and evangelizing mission of the diocesan schools, the strong alignment of the educational objectives, programs, and governance with the directions of the Church along with the common understanding of the stakeholders is essential. Hence, regular induction and collaboration should be in place. Meanwhile, to ensure the operational 
viability and sustainability of diocesan schools, the adherence of the leaders to the directives of the government, the retention of qualified and committed teachers, and the continuous faith and professional formations of the personnel are vitally necessary.

Practical Value of the Paper. The study encourages future researchers to explore more on the five areas of PCSS standards to fully understand the factors that affect the quality of Catholic education. The findings of the study have provided the researcher with the basis in the formulation of an Enhanced Catholic Education Plan for the continuous growth and development of the diocesan schools relative to the offering of quality education.

\section{References}

Belmonte, A. \& Cranston, N. (2009). The Religious Dimension of Lay Leadership in Catholic Schools: Preserving Catholic Culture in an Era of Change. Journal of Catholic Education, 12(3), 294-319.

Bual, J. \& Madrigal, D. (2018). The Quality of Catholic Education in a Diocesan School Relative to the Philippine Catholic School Standards. Philippine Social Science Journal, 1(1), 41-53.

Cook, T. J. \& Simonds, T. A. (2011). The Charism of 21st-Century Catholic Schools: Building a Culture of Relationships. Catholic Education: A Journal of Inquiry and Practice, 14(3).

Garcia-Huidobro, J. C. (2017). What are Catholic Schools teaching to make a Difference? A Literature Review of Curriculum Studies in Catholic Schools in the US and the UK since 1993. Journal of Catholic Education, 20(2), n2.

Madrigal, D. V. \& Oracion, E. G. (2019). The Quality of Recoletos Education in Negros Island in the Realm of Philippine Catholic School Standards. Recoletos Multidisciplinary Research Journal, 7(1), 1-12.

McDonough, G. P. (2010). The Problem of Catholic School Teachers deferring to the Home on Controversial Religious Issues. Catholic Education: A Journal of Inquiry and Practice, 13(3), 287-305.

O'Keefe, J. M. \& Goldschmidt, S. E. P. (2014). Courageous, Comprehensive, and Collaborative. Catholic schools in the Public Interest: Past, Present, and Future Directions, 221.

Ozar, L. A. (2012). National Catholic School Standards: An Accountable Vision of Catholic Schools for our Times. Journal of Catholic School Studies, 84(2).

Ozar, L. \& Weitzel-O'Neill, P. (2013). National Catholic School Standards: Focus on Governance and Leadership. Journal of Catholic Education, 17(1), 157-162

Spesia, D. D. (2016). Forming Catholic School Principals as Leaders of the New Evangelization. Journal of Catholic Education, 20(1), n1.

\section{Correspondence:}

Rita O. Banusing [rita_banusing21@yahoo.com]

https://orcid.org/0000-0002-4051-1281 